\title{
Reasons of Choosing Recreation Management Departments within the Body of Tourism Faculties and Expectations of Students
}

\section{Turizm Fakülteleri Bünyesinde Rekreayon Yönetimi Bölümlerinin Tercih Edilme Nedenleri ve Bölüm Öğrencilerinin Beklentileri}

\author{
Ercan YAVUZ ${ }^{1}$ \\ Gazi University \\ Mustafa AKSOY² \\ Gazi University \\ Ali İSKENDER ${ }^{3}$ \\ Gazi University
}

\begin{abstract}
It is seen that the students graduating from Recreation department work in tourism sectors, but on the other hand, Recreation students can also work in industry and domestic administrations, school recreation, therapeutic recreation etc. This paper presents some solutions by determining that the Recreation administration program's students' expectations of future and sufficiency of their education and their happiness.

Key Words: Tourism, Tourism Faculty, Recreation Management

\section{Özet}

Rekreasyon bölümleri mezunlarının ağırlıklı istihdam alanlarının turizm sektörü olduğu görülmektedir. Rekreasyon bölümlerinin istihdam alanları turizm dışında çok daha geniş bir alanı kapsamaktadır. Bölüm öğrencileri; sanayi ve yerel yönetimler rekreasyonu, turizm rekreasyonu, okullar rekreasyonu, terapatik rekreasyon gibi alanlarda uzmanlaşarak mezun olabilirler. Bu çalışma Turizm Fakülteleri bünyesinde daha yeni yeni açılmaya başlayan Rekreasyon Yönetimi Bölümünün öğrencilerinin bölümle ilgili geleceğe dair beklentilerini, üniversitede aldıkları eğitimin yeterliliğini ve öğrencilerin memnuniyet durumlarını tespit ederek çözüm önerileri sunmaktadır.
\end{abstract}

Anahtar Kelimeler: Turizm, Turizm Fakültesi, Rekreasyon Yönetimi

\footnotetext{
${ }^{1}$ Asst. Prof. Dr., Gazi University, Tourism Faculty, Recreation Management Department, eyavuz@gazi.edu.tr

2 Asst. Prof. Dr., Gazi University, Tourism Faculty, Gastronomy and Culinary Arts Department, maksoy@gazi.edu.tr

${ }^{3}$ Research Assistant, Gazi University, Tourism Faculty, Recreation Management Department, aliiskender@gazi.edu.tr
} 


\section{Introduction}

According to Turkish Language Institution, expectation is explained as prospecting something to happen or; forecasting of individual forms to receive certain terms and conditions or predictions about expectations of somebody himself. In the context of this research, future expectations are seen the situations in which students are forecasting to happen (Tuncer, 2011). It is quite important that the meeting the expectation needs of students and determining what students forecast to provide services beyond these expectations. It is valuable to clarify the expectations of students in terms of student satisfaction and provided service quality (Şahin, 2011).

In the higher education field, which is ranked among service industry, growing interest in quality has become more important with competition. The number of higher education institutions is increasing incrementally. Correspondingly, increasing competition between universities is the major reason that led service provider institutions to quest for higher quality. If there is a negative correlation between expected and perceived quality for those who are evaluating the service quality, there can be a negative attitude towards quality. On the other hand, if the difference is positive, it can be said that the evaluation will be also positive (Okumuş, 2008).

\section{Conceptual Framework}

In Latin language, creating something new, renewal, meaning recreate derived from the word recreation means born again, to renewed and psychologically innovation in dictionary. Recreation can be expressed as renewed separated from the life of monotony and work (Çoruh, 2013). Recreation also means to relax, to entertain and to revive. People in their spare time are attending various kinds of different entertaining activities with the purpose of getting away, relaxing, exciting, sightseeing, health, gathering together with others and obtaining diversified experiences. Those activities can be held on both inside and outside, within the city or rural areas, in an active or passive way. At this point, recreation is a term that describes those leisure time activities (Özen, 2011).

Recreation contributes greatly to maintain the healthy being of physical and mental health of people who are under intensive workload, routine lifestyle; and the stressful environmental effects on the body (Karaküçük, 2010). At the same time, recreation can also be explained as the optional activities which are conducted in the leisure time individually or in group. the recreational activities are based on voluntariness for the purpose of getting personal satisfaction (Cerit, 2008). Individual, psychological, physical and social activities that the person is attending voluntarily to achieve some benefits are all within the scope of the recreation. Recreation symbolizes the combination between game and leisure time activities. Recreation includes sports, physical exercise, games, crafts, music, travel, hobbies, fine arts and social activities (Tolukan, 2010). 
Boredom which is created by ongoing uniformity and routine is generally overcame by change with recreational activities, bringing innovation and interestingness. This can be seen as an obligation for today's people' complicated lives (Karaküçük, 2010).

According to Tütüncü (2008), classification of recreation through the purposes of it may help to provide better service as follows:

- Recreation in tourism

- Recreation in industry and local government

- Therapeutic recreation

- Military recreation

- Recreation in education (children, youth, elders, pregnant women and recreation for the disabled people).

Based on this classification, Tütüncü (2008) proposes to give importance to suggestions below in order to reach the level of developed countries in terms of recreation in Turkey;

- Implementation of legal regulations to diversified recreation

- Opening recreation departments according to the purpose and giving emphasis on quality,

- Legislating local governmental laws

- Cooperation between the Ministry and the General Directorate to make regulations for recreational sports tourism which is an important alternative for tourism,

- Dissemination of promotion and awareness of society via mass media

\section{The Purposes of Recreation Departments}

The main objective of the Recreation Management department is to train the required people, in the zone of public and private sector, who are welleducated, able to follow developments in the field, equipped with management skills, specialized in the recreation area, physically qualified to adapt mobility and the people who have good communication skills to enable mutual communication (www.ikc.edu.tr). Moreover, educating professionals in the field developing the quality and standards of management structure of the entertainment of Turkey's tourism recreation and the animation, affectively managing the present and future needs of sector and producing influential solutions is at the core of the main goals of department. (www.akdeniz.edu.tr).

\section{Career Opportunities}

Intermediate staff who will graduate from this program can be employed in the following areas (Zorba et al, 2003)

The area of health; 
- In public, university or private hospitals

- In rehabilitation centers,

- In physical therapy centers,

- In the field of hospitality and service,

The area of service;

- In sport facilities,

- In service delivery areas of manufacturing sector,

- Local governments (municipalities),

- In schools,

- General Directorate of Youth (in youth camps) and,

- In universities.

The area of tourism;

- Water sports animator of recreational activities,

- Land sports animator of recreational activities,

- Air sports animator of recreational activities (paragliding, paramotor, etc.).

- Socio-cultural recreational activities animator (folk games, dances, music, festivals, exhibitions etc.).

- Animator for recreational activities in health tourism facilities

- Children animator of recreation activities (www.cbe.edu.tr)

\section{General Curriculum of the Department}

The students can only apply the recently opened department of Recreation Management in Gazi University Faculty of Tourism throughout the country. Subjects and lessons covered in the department are as follows in general. (www.gazi.edu.tr)

- Recreation Management

- Recreational Activities

- Recreation Policy and Planning

- Animation Services

- Recreational Area Design

- Recreation Program Planning

- Animation Applications

- Tourism and Environment

- Recreation and Urbanization

- Therapeutic Recreation

- Facility management

- Creative Drama

- Park Management

- Interior Design and Concept

- Recreation and Sports 
Common elective courses which are taught in other departments (Tourism Management, Gastronomy and Culinary Arts, Travel Management and Tourism Guidance) are also offered for students' choice.

\section{Research Method}

This research has been applied to the students who are studying at Gazi University Faculty of Tourism in Recreation Management. Surveys have been used as the data collection method. The survey has been conducted with first, second, third and fourth grade students of Recreation Management students. The research population is consisted of 630 students. There are 450 people surveyed in total. However, data were analyzed by counting a total of 400 people on invalid reasons of remained 50 people. The first part of the survey's includes questions such as gender, age, marital status, class, geographic region, ideas and thoughts about after graduation and sector-based employment. The second part consists of the 5 Likert Scale items which measures both the students' reasons to choose the department and expectations. Master's thesis of Cerit (2008) has been referred tin the process of creation of scale.

\section{Analysis and Results}

Data analysis was performed with SPSS software V.19. Research has been applied to recreation management department students and 400 data has been found eligible for analysis from the total of 450 .

Table 1. Identifier Demographic Information of Students

\begin{tabular}{|c|l|l|}
\hline GENDER & $n$ & $\%$ \\
\hline Male & 185 & 46,3 \\
\hline Female & 215 & 53,8 \\
\hline AGE & & \\
\hline $19-22$ & 302 & 75,5 \\
\hline $23-26$ & 88 & 22 \\
\hline Over 26 & 10 & 2,5 \\
\hline YEAR & & \\
\hline 1. Year & 77 & 19,3 \\
\hline 2. Year & 129 & 32,3 \\
\hline 3. Year & 71 & 17,8 \\
\hline 4. Year & 123 & 30,8 \\
\hline & & \\
\hline & & \\
\hline & &
\end{tabular}




\begin{tabular}{|c|l|l|}
\hline MARITAL STATUS & & \\
\hline Married & 11 & 2,8 \\
\hline Single & 389 & 97,3 \\
\hline GEOGRAPHICAL REGION & & \\
\hline Marmara Region & 80 & 20 \\
\hline Aegean Region & 68 & 17,0 \\
\hline Mediterranean Region & 54 & 13,5 \\
\hline Central Anatolia Region & 126 & 31,5 \\
\hline Black Sea Region & 48 & 12,0 \\
\hline Southeast Region & 11 & 2,8 \\
\hline East Anatolia Region & 13 & 3,3 \\
\hline
\end{tabular}

In Table 1 , it is shown that $46.3 \%$ of the students were male, and $53.8 \%$ were female. It is appeared that $75.5 \%$ of students were in the age range 19 $22,22 \%$ were in the $23-26$, and $2.5 \%$ were in the 26 and over age range. According to table 1 , it can be seen that $19.3 \%$ of students were in the first grade, $32.3 \%$ were in the second, $17.8 \%$ were in the third, and $30.8 \%$ were in the fourth year of studying. The geographical areas which students came from are seen in table 1 as follows: $20 \%$ of students comes from the Marmara region, $17 \%$ from the Aegean region, $13.5 \%$ in the Mediterranean region, $31.5 \%$ in Central Anatolia, the Black Sea region of $12 \%, 2.8 \%$ in South-East Anatolia of the, while 3.3\% comes from the Eastern Anatolia region. Central Anatolia region is the predominate one which students came to the department from. It is believed that the role of the proximity factor takes place in this situation. Southeastern Anatolia region is in the minority according to the student presence.

Table 2. Expectations of Undergraduate Students

\begin{tabular}{|l|l|l|}
\hline & $\underline{\text { YES }}$ & $\underline{\text { NO }}$ \\
\hline Do you want to have a master's degree? & $267(66,8 \%)$ & $133(33,3 \%)$ \\
\hline & $\underline{\text { PUBLIC }}$ & $\underline{\text { PRIVATE }}$ \\
\hline Which field do you want to work for? & $228(57 \%)$ & $172(43 \%)$ \\
\hline
\end{tabular}




\begin{tabular}{|l|l|l|}
\hline $\begin{array}{l}\text { Industry preference for those who want to } \\
\text { work in the private sector }\end{array}$ & $\underline{\underline{Y E S}}$ & $\underline{\underline{N}}$ \\
\hline Recreation Businesses & $100(58,1 \%)$ & $72 \quad(41.9 \%)$ \\
\hline Organization Businesses & $123(71,8 \%)$ & $49 \quad(28,5 \%)$ \\
\hline Health and Wellness Tourism & $\begin{array}{l}65 \\
(37,8 \%)\end{array}$ & $107(62,2 \%)$ \\
\hline Sports Businesses & $78(45,3 \%)$ & $94 \quad(54,7 \%)$ \\
\hline Shopping Malls & $40(23,3 \%)$ & $132(76,7 \%)$ \\
\hline Accommodation Establishments & $61(35,5 \%)$ & $111(64,5 \%)$ \\
\hline The Animation and Entertainment Business & $63(36,6 \%)$ & $109(63,4 \%)$ \\
\hline
\end{tabular}

Table 2 measures the expectations of undergraduate students after graduation. According to the table, it is seen that $66.8 \%$ rate of the students are thinking about having a master's degree. In addition, it can be seen that majority of the students want to work in public institutions. $57 \%$ of the students want to be employed in the public sector, while $43 \%$ stated that they wish to be employed in the private sector. Also, the detailed name of the private sectors can be seen in table $2.58 \%$ of the total number of 172 students stated that they want to work in the recreation businesses; yet, $41.9 \%$ mentioned that they do not want. Furthermore, $71.8 \%$ of the students has stated that they are tend to work for organisational businnesses, $37.8 \%$ are in the field of health and medical tourism, $45.3 \%$ in the sports business, $23.3 \%$ in the shopping centers, $35.5 \%$, in accommodation establishments while $36.6 \%$ stated that they want to work in animation and entertainment businesses. The minority is on the working in the field of shopping centers with the rate of $76 \%$, followed by the rate of $64,5 \%$ in accommodation businesses. Despite the fact that animation and entertainment industry has a high proportion of very closely related to their profession area of expertise, $63.4 \%$ of students stated that they were not thinking of working in this sector. Similarly, health and medical tourism can also be seen as their separate branch of specialization; yet, the students were also mentioned not to work for this field.

Table 3. Information of Sector in Which Students are Tend to Work for According to Their Gender

\begin{tabular}{|l|l|l|r|r|r|}
\hline \multicolumn{2}{|c|}{} & \multicolumn{2}{c|}{ Sector } & \multirow{2}{*}{ Total } \\
\cline { 3 - 6 } \multicolumn{2}{|c|}{} & Female & Public & \multicolumn{1}{c|}{ Private } & \multicolumn{1}{c|}{ Count } \\
\cline { 3 - 6 } & \% within gender & 137 & $78,7 \%$ & $36,3 \%$ & $100,0 \%$ \\
\cline { 2 - 6 } & Male & Count & 91 & 94 & 185 \\
\hline
\end{tabular}




\begin{tabular}{|l|l|l|r|r|r|}
\hline & $\%$ within gender & $49,2 \%$ & $50,8 \%$ & $100,0 \%$ \\
\hline \multirow{2}{*}{ Total } & Count & 228 & 172 & 400 \\
\cline { 2 - 5 } & $\%$ of Total & $57,0 \%$ & $43,0 \%$ & $100,0 \%$ \\
\hline \multicolumn{2}{|l}{$\mathrm{X}^{2=P<0,05}$} &
\end{tabular}

Table 3 shows that there is a significant difference between students looking at the sectors that are willing to work according to gender $(P<0.05)$. $63.7 \%$ of the female students stated that they want to work in the public sector after graduation. In male students, this ratio is as $49.2 \%$. Female students would like to work in public institutions more than males.

Table 4. Students' Reasons to Choose the Department and Expectations About the Department

\begin{tabular}{|c|c|c|c|c|c|}
\hline & $\begin{array}{l}\text { Strongly } \\
\text { Disagree }\end{array}$ & Disagree & $\begin{array}{c}\text { Moderately } \\
\text { Agree }\end{array}$ & Agree & Totally Agree \\
\hline $\begin{array}{l}\text { I selected recreation } \\
\text { department for academic } \\
\text { career. }\end{array}$ & $56(\% 14,0)$ & $93(\% 23,3)$ & $112(\% 28,0)$ & $95(\% 23,8)$ & $44(\% 11)$ \\
\hline $\begin{array}{l}\text { I selected recreation } \\
\text { department because of } \\
\text { my university entrance } \\
\text { exam score. }\end{array}$ & $119(\% 29,8)$ & $109(\% 27,3)$ & $89(\% 22,3)$ & $54(\% 13,5)$ & $29(\% 7,3)$ \\
\hline $\begin{array}{l}\text { I selected recreation } \\
\text { department with } \\
\text { guidance. }\end{array}$ & $88(\% 22)$ & $88(\% 22)$ & $85(\% 21,3)$ & $104(\% 26,0)$ & $35(\% 8,8)$ \\
\hline $\begin{array}{l}\text { I selected recreation } \\
\text { department for being a } \\
\text { teacher. }\end{array}$ & $69(\% 17,3)$ & $103(\% 25,8)$ & $106(\% 26,5)$ & $68(\% 17,0)$ & $54(\% 13,5)$ \\
\hline $\begin{array}{l}\text { I think the academic } \\
\text { staff of my department } \\
\text { are sufficient. }\end{array}$ & $42(\% 10,5)$ & $62(15,5)$ & $117(29,3)$ & $134(\% 33,5)$ & $45(\% 11,3)$ \\
\hline $\begin{array}{l}\text { I do not think that the } \\
\text { curriculum is enough and } \\
\text { efficient at my } \\
\text { department. }\end{array}$ & $44(\% 11,0)$ & $76(\% 19,0)$ & $100(\% 25,0)$ & $105(\% 26,3)$ & $75(\% 18,8)$ \\
\hline $\begin{array}{l}\text { I do not think that the } \\
\text { class hours of my } \\
\text { department is enough. }\end{array}$ & $47(\% 11,8)$ & $94(\% 23,5)$ & $129(\% 32,3)$ & $68(\% 17,0)$ & $62(\% 15,5)$ \\
\hline $\begin{array}{l}\text { I find the applications of } \\
\text { lessons taught in my } \\
\text { department inadequate. }\end{array}$ & $30(\% 7,5)$ & $48(\% 12,0)$ & $82(\% 20,5)$ & $109(\% 27,3)$ & $131(\% 32,8)$ \\
\hline
\end{tabular}




\begin{tabular}{|c|c|c|c|c|c|}
\hline $\begin{array}{l}\text { I do not think that I will } \\
\text { have an internationally } \\
\text { recognized diploma, and } \\
\text { have enough } \\
\text { competence at sector } \\
\text { after graduation from my } \\
\text { department. }\end{array}$ & $54(\% 13,5)$ & $60(\% 15,0)$ & $144(\% 36,0)$ & $109(\% 27,3)$ & $33(\% 8,3)$ \\
\hline $\begin{array}{l}\text { I do not think that I have } \\
\text { received well consulting } \\
\text { services related to the } \\
\text { courses given by my } \\
\text { department. }\end{array}$ & $35(\% 8,8)$ & $72(\% 18,0)$ & $150(\% 37,5)$ & $102(\% 25,5)$ & $41(\% 10,3)$ \\
\hline $\begin{array}{l}\text { I do not think that the } \\
\text { academic studies related } \\
\text { with my department is } \\
\text { enough. }\end{array}$ & $32(\% 8,0)$ & $74(\% 18,5)$ & $123(\% 30,8)$ & $110(\% 27,5)$ & $61(\% 15,3)$ \\
\hline $\begin{array}{l}\text { I would like to switch } \\
\text { Recreation Management } \\
\text { department to another. }\end{array}$ & $106(\% 26,5)$ & $129(\% 32,3)$ & $85(\% 21,3)$ & $50(\% 12,5)$ & $30(\% 7,5)$ \\
\hline $\begin{array}{l}\text { I am not very clear } \\
\text { about my future career. }\end{array}$ & $43(\% 10,8)$ & $66(\% 16,5)$ & $106(\% 26,5)$ & $100(\% 25,0)$ & $85(\% 21,3)$ \\
\hline $\begin{array}{l}\text { I am concerning for } \\
\text { employment in my } \\
\text { profession. }\end{array}$ & $37(\% 9,3)$ & $66(\% 16,5)$ & $113(\% 28,3)$ & $99(\% 24,8)$ & $85(\% 21,3)$ \\
\hline $\begin{array}{l}\text { I have not enough } \\
\text { knowledge about the } \\
\text { workspaces and } \\
\text { opportunities about my } \\
\text { profession. }\end{array}$ & $48(\% 12,0)$ & $85(\% 21,3)$ & $117(\% 29,3)$ & $95(\% 23,8)$ & $55(\% 13,8)$ \\
\hline $\begin{array}{l}\text { I do not think that I } \\
\text { made a right choice to } \\
\text { select Recreation } \\
\text { Management } \\
\text { department. }\end{array}$ & $66(\% 16,5)$ & $100(\% 25,0)$ & $117(\% 29,3)$ & $67(\% 16,8)$ & $50(\% 12,5)$ \\
\hline $\begin{array}{l}\text { I think it is not beneficial } \\
\text { to open Recreational } \\
\text { Management department } \\
\text { within the body of } \\
\text { Tourism Faculties. }\end{array}$ & $139(\% 34,8)$ & $102(\% 25,5)$ & $76(\% 19,0)$ & $46(\% 11,5)$ & $37(\% 9,3)$ \\
\hline
\end{tabular}

Table 4 shows the responses of participants in terms of 5 Likert scale. According to table 4; it can understood that totally \%11(totally agree) and $\% 23,8$ (agree) of the participants choose recreation department in order to make academic carriers. Namely it shows that $\% 34,8$ of students expect to 
make academic carrier in this field of study. \%29,8 (strongly disagree) and $\% 27.3$ (disagree) of the participants described that they didn't choose this branch due to the university entrance exam score, namely they chose this department voluntary not mandatory. \%22 (strongly disagree) and \%22 (disagree) of the participants chose this department by not taking any guidance. According to table 4, the percentage of students who chose this department in order to be teacher is 13,5 (strongly agree) and \%17 (agree). As for the ones who didn't have aim to be teacher is \%17,3 (strongly disagree) and \%25,8 (disagree). The percentage of students who accept as their academicians sufficient is $\% 11,5$ (totally agree) and $\% 33,5$ (agree). The percentage of students who describe that the curriculum of department not enough is $\% 18,8$ (totally agree) and \%26,3 (agree). The percentage of students who describe the class hour of department not enough \%15,5(totally agree) and \%17 (agree). The percentage of students who describe that practicable lecture as not adequate is $\% 32,8$ (totally agree) and 27,3 (agree). The percentage of students who described that after their graduation, their diploma will be recognized at an international level and have a enough competences for sector is \%8,3 (totally agree) and 27,3(agree). The percentage of students thinking as consulting service relating with courses in department as not enough is \%10,3 (totally agree)and \%25,5(agree). The percentage of students evaluating the academic studies in department as not enough is 15,3 (totally agree) and 27,5 (agree). The percentage of students who think to change their department with another one is $\% 7,5$ (totally agree) and $\% 12,5$ (agree). The percentage of students who have future anxiety about their career is \%21,3(totally agree) and \%25 (agree). The percentage of students who have suspicious about employment in future about their profession is \%21,3 (totally agree) and \%24,8(agree). The percentage of students who think that they don't have knowledge about where to work and what to opportunities of their profession is 13,8 (totally agree) and 23,8 (agree). The percentage of students who think to choose this department as a wrong and bad choice is \%12,5 (totally agree) and \%16,8(agree).

Table 5. Students' Reasons to Choose the Department and Average of Expectations

\begin{tabular}{|l|r|r|r|r|r|}
\hline & $N$ & Min. & Max & Average & $\begin{array}{r}\text { Std. } \\
\text { Dev. }\end{array}$ \\
\hline I selected recreation department for academic career. & 400 & 1 & 5 & 2,95 & 1,213 \\
\hline $\begin{array}{l}\text { I selected recreation department because of my university } \\
\text { entrance exam score. }\end{array}$ & 400 & 1 & 5 & 2,41 & 1,243 \\
\hline I selected recreation department with guidance. & 400 & 1 & 5 & 2,77 & 1,290 \\
\hline I selected recreation department for being a teacher. & 400 & 1 & 5 & 2,84 & 1,279 \\
\hline I think the academic staff of my department is sufficient. & 400 & 1 & 5 & 3,20 & 1,151 \\
\hline $\begin{array}{l}\text { I do not think that the curriculum is enough and efficient at my } \\
\text { department. }\end{array}$ & 400 & 1 & 5 & 3,23 & 1,263 \\
\hline $\begin{array}{l}\text { I do not think that the class hours of my department is enough. } \\
\text { I find the applications of lessons taught in my department } \\
\text { inadequate. }\end{array}$ & 400 & 1 & 5 & 3,01 & 1,224 \\
\hline
\end{tabular}




\begin{tabular}{|c|c|c|c|c|c|}
\hline $\begin{array}{l}\text { I do not think that I will have an internationally recognized } \\
\text { diploma, and have enough competence at sector after } \\
\text { graduation from my department. }\end{array}$ & 400 & 1 & 5 & 3,02 & 1,138 \\
\hline $\begin{array}{l}\text { I do not think that I have received well consulting services } \\
\text { related to the courses given by my department. }\end{array}$ & 400 & 1 & 5 & 3,11 & 1,089 \\
\hline $\begin{array}{l}\text { I do not think that the academic studies related with my } \\
\text { department are enough. }\end{array}$ & 400 & 1 & 5 & 3,24 & 1,157 \\
\hline $\begin{array}{l}\text { I would like to switch Recreation Management department to } \\
\text { another. }\end{array}$ & 400 & 1 & 5 & 2,42 & 1,216 \\
\hline I am not very clear about my future career. & 400 & 1 & 5 & 3,30 & 1,270 \\
\hline I am concerning for employment in my profession. & 400 & 1 & 5 & 3,32 & 1,238 \\
\hline $\begin{array}{l}\text { I have not enough knowledge about the workspaces and } \\
\text { opportunities about my profession. }\end{array}$ & 400 & 1 & 5 & 3,06 & 1,217 \\
\hline $\begin{array}{l}\text { I do not think that I made a right choice to select Recreation } \\
\text { Management department. }\end{array}$ & 400 & 1 & 5 & 2,84 & 1,247 \\
\hline $\begin{array}{l}\text { I think it is not beneficial to open Recreational Management } \\
\text { department within the body of Tourism Faculties. }\end{array}$ & 400 & 1 & 5 & 2,35 & 1,308 \\
\hline
\end{tabular}

Table 5 shows the average distribution of students according to their responses to items on the questionnaire. Strongly Disagree (1) Disagree (2) Agree Moderately (3), Agree (4) Strongly Agree (5) questions were asked students to respond while shaping the feedbacks according to the Likert 5 measurement. Ratings range from negative to positive. According to information obtained from the table, the students stated that they saw the curriculum not enough for application areas with the highest average with 3.66 , they also said they had concerns about the future of employment in occupations with an average of 3.32. With an average 3.30, students mentioned that they are not clear about their future career in this field. Students who have average 3.24 saw the academic studies insufficient in their department, while average 3.23 found the curriculum and classes are not enough. In addition to this, students with average 3.20 mentioned that they found the academic staff of the department is well-equipped and sufficient. With the average of 3.11, students do not think that they have received well consulting services related to the courses given by the department. Students have reported negative opinions about their department and have expressed concerns about their future. The lowest average of 2.35 values the statement of "I think it is not beneficial to open Recreational Management department within the body of Tourism Faculties". As understood from here, most of the students found right to open Recreation Management department within the body of tourism faculties. With the average of 2.41 , students indicated that they preferred this department because of the score in the university entrance exams. Students with an average of 2.42 indicated that they want to switch to another department. The average is lower for those who want to change the department. When looking at the 
reasons for the choice of the students with the highest average 2.95 stated that they would prefer to make academic career in this field. Then it is seen that they prefer to be a teacher with an average of 2.84 . The percentage of those who prefer department with guidance is 2.77 .

\section{Suggestions}

According to the results of research, the students of department of Recreation Management have some doubts and uncertainties related to the department. Student employment concerns have emerged especially after they had graduated. Besides, students saw the curriculum, courses and counseling service of the department insufficient.

Students are mentioning that they do not know well enough about the professional and specialization areas of study. The students with the highest average are complaining about inadequate application of the courses. In this case, it is highly recommended to reduce the practical emphasis in the core subjects of Recreation Management department, rather than theoretical course load. In order to adapt students to the department and resolve their doubts and concerns related to field, industry representatives or the people those who work in this field should be invited to broaden students' horizons about their presence. Academic counseling services offered to students must be increased. According to table 2, it can be commented that students are avoiding the businesses (Health Tourism, Leisure and Entertainment Businesses, etc.) that require special skills and specialization in their field of profession. There can be foreseen that the lack of implementation of courses related to this field or the effect may be mainly theoretical course load.

\section{References}

Akbaba A., B.E, Güru, Yaran,M., Çimen ,H.,(2006) "Öğrencilerin Öğretim Elemanları ile İlgili Kalite Beklentileri: Akçakoca Turizm İşletmeciliği ve Otelcilik Yüksekokulu Örneği", Anatolia turizm Araştırmaları Dergisi, Sayı 1

Akman, Y., (1992), "Hacettepe Üniversitesi Eğitim Fakültesi Öğrencilerinin Meslek Evlilik ve geleceğe Dair Beklentileri", H.Ü Eğitim Fakültesi Dergisi, Sayı, 7

Cerit, E., (2008),"Beden Eğitimi ve Spor Yüksekokulları Bünyesinde Rekreasyon Bölümlerinin Tercih Edilme Nedenleri ve Bölüm Öğrencilerinin Beklentileri", Yayınlanmamış Yüksek Lisans Tezi, Muğla Üniversitesi Sosyal Bilimler Enstitüsü, Muğla, s.51

CAN, H. Organizasyon ve Yönetim , Siyasal Kitabevi, 3. Baskı, 2008

Çoruh, Y., (2013), "Üniversite Öğrencilerinin Rekreasyonel Eğilimleri ve Rekreasyonel Etkinliklere Katıımına Engel Olan faktörler", Gazi Üniversitesi Sağlık Bilimleri Enstitüsü, Ankara, s.12-20 
Gonca, Ş.G, (2011) "Üniversite Düzeyinde Turizm Eğitiminde Hizmet Kalitesi Beklenti ve Algısına Yönelik Ankara'da Bir Araştırma", sayı,3/4Özen, G.,(2011), "Rekreasyon bölümü Mezunlarının İstihdam Durumlarının belirlenmesi", Gazi Üniversitesi Sağlık Bilimleri Enstitüsü, Ankara, s. 13-20

Karaküçük, S., (2008) , Rekreasyon Boş Zaman Değerlendirme, Gazi Kitabevi, Altıncı Baskı,

Okumuş, A., Duygun, A. (2008) "Eğitim Hizmetlerinin Pazarlanmasında Hizmet Kalitesinin Ölçümü ve algılanan Hizmet Kalitesi ile Öğrenci Memnuniyeti Arasındaki İlişki" Anadolu Üniversitesi sosyal Bilimler Dergisi, Sayı, 2,

Tütüncü, Ö., (2012)," Rekreasyon Yönetimi'ne Yönelik Üniversite düzeyinde Bir Müfredat Geliştirme Önerisi", Anatolia Turizm Araştırmaları Dergisi, sayı 1,

Tütüncü, Ö., (2012)," Rekreasyonda kurumsallaşma ve Uzmanlaşma", Anatolia Turizm Araştırmaları Dergisi, sayı 1,

Tolukan, E., (2010), "Özel Yetenekle İlgili Bölümlerde Okuyan Üniversite Öğrencilerinin Rekreasyonel Aktivitelere Katılımlarına Engel Olabilecek Unsurların Belirlenmesi", Niğde Üniversitesi Sosyal Bilimler enstitüsü, , Niğde, s.15-16

Tuncer, M., (2011) "Yükseköğretim Gençliğinin Gelecek beklentileri Üzerine Bir Araştırma", International Periodical For The Languages, Literature and History of Turkish or Turkic, Volume, 6/2,

Zorba,E., Kömür, Ş., Miçooğulları, O., (2003), "Comparison and Analysis of Sportive Recreation/Animation Programmes Between Holiday Villages and 4-5 Stars Hotels", International Conference on Higher Education Innovation, Kiev, p.2007

\section{Internet References}

http://besyo.cbu.edu.tr/rekreasyon.asp

http://turizm.ikc.edu.tr/akademik/rekreasyon-yonetimi

http://www.ebs.sakarya.edu.tr/?upage $=$ fak\&page $=$ bol\&f $=10 \& b=02 \& c h=1 \& y i l=$ 2013\&lang=tr\&cpage =amachedef

http://gbp.gazi.edu.tr//htmIProgramHakkinda.php?dr=0\&lang =0\&FK=19\&BK=0 6\&ders_kodu $=\&$ fakulte $=$ TUR\%DDZM+FAK\%DCLTES\%DD\&fakulte_en $=$ FACULTY +OF+TOURISM\&bolum $=$ REKREASYON+Y\%D6NET\%DDM\%DD\&bolum_en=REC REATION+MANAGEMENT\&aC $=11$ 